Meta

Journal des traducteurs

Translators' Journal

\title{
Towards a Methodology for the Translation of Japanese Patent Claims
}

\section{Robert Matthew}

Volume 36, numéro 2-3, juin 1991

URI : https://id.erudit.org/iderudit/003602ar

DOI : https://doi.org/10.7202/003602ar

Aller au sommaire du numéro

Éditeur(s)

Les Presses de l'Université de Montréal

ISSN

0026-0452 (imprimé)

1492-1421 (numérique)

Découvrir la revue

Citer cet article

Matthew, R. (1991). Towards a Methodology for the Translation of Japanese Patent Claims. Meta, 36(2-3), 382-403. https://doi.org/10.7202/003602ar
Résumé de l'article

Le but de cette recherche est l'étude des brevets d'invention japonais, plus spécifiquement des réclamations concernant ces brevets. L'accent est mis sur le vocabulaire et le style, et plus encore sur la structure syntaxique. Les régularités sont ici recherchées dans l'intention de les soumettre à une explication systématique. Cet essai devrait faciliter tout d'abord la compréhension de leur structure, ensuite leur traduction en anglais et finalement rendre possible la mise sur pied d'un système d'encodage numérique qui pourra être d'un grand secours en traduction automatique nécessitant un minimum de post-rédaction. 


\title{
TOWARDS A METHODOLOGY FOR THE TRANSLATION OF JAPANESE PATENT CLAIMS
}

\author{
ROBERT MATTHEW \\ Department of Japanese and Chinese Studies, \\ University of Queensland, Australia
}

\begin{abstract}
RÉSUMÉ
Le but de cette recherche est l'étude des brevets d'invention japonais, plus spécifiquement des réclamations concernant ces brevets. L'accent est mis sur le vocabulaire et le style, et plus encore sur la structure syntaxique. Les régularités sont ici recherchées dans l'intention de les soumettre à une explication systématique. Cet essai devrait faciliter tout d'abord la compréhension de leur structure, ensuite leur traduction en anglais et finalement rendre possible la mise sur pied d'un système d'encodage numérique qui pourra être d'un grand secours en traduction automatique nécessitant un minimum de post-rédaction.
\end{abstract}

\section{SUMMARY}

The object of this current research is a study of Japanese patents and in particular a study of patent claims. Attention is focussed on their vocabulary and style and especially on their syntactic structure. Here regularities are sought with the intention of subjecting them to a systematic explanation. It is hoped that this explanation will facilitate 1) an understanding of their structure 2) their translation into English and 3) eventually a possible numerical encoding system that may be of assistance in mechanical translation with a minimum of postediting.

\section{RATIONALE AND BACKGROUND}

\section{The Significance of Japanese Patents}

Japanese patent applications today are running well in excess of half a million a year, dwarfing the American figure. Although Japan has long been considered to be "a nation of copiers" merely managing better the production of products devised elsewhere, the rate of patent applications belies this traditional Western popular conception. It is underpinned by the high graduation rate in such subjects as engineering and is emphasized by a shift in Japan's favour in the direction of royalty payments. It indicates that those nations which wish to remain at the forefront of technology must increasingly keep abreast of the latest Japanese technology. An awareness of Japanese patents may be regarded as an essential prerequisite for achieving this. It may also be that technological innovation readily represented in patent applications is an important index of a society's dynamism. It is not necessarily the only such index but it is hard to deny that a society with a huge lead of at least four to one over its nearest competitor is not at the cutting edge of human development.

Many important consequences flow from this. The economic influences are plain enough, and many geopolitical questions are raised as well. Intellectual property (largely a matter of patents but also including copyright, design and trademarks) is becoming an increasingly vexing question in GATT and bilateral negotiations, and in a shrinking world 
differing legal concepts and systems come increasingly into conflict, with powerful national interests at stake. Trade friction is increasingly seen to include "intellectual property friction", and in the information society of the future it may well be that he who controls information (i.e. he whose property it is) controls the world. Political, economic, legal and industrial considerations all indicate a growing pressure upon the rest of the world to be aware of Japan's technological progress, and that nation's patent claims are the most ready and direct means of gaining information about that progress.

To the best of my knowledge no systematic attempt is made in the U.S. to have Japanese patent claims or abstracts translated on a regular basis: individual firms must fend for themselves as best they can. The E.C. has commissioned the translation of 10,000 abstracts a year but this is only skimming the surface. Soviet efforts are unknown, but it is clear that in the West at least there is an enormous gap in knowledge about what is going on in Japan.

\section{The Philosophy of Patents}

The strict meaning of a patent is defined in law and it should not be assumed that the meaning is the same in different legal jurisdictions. In particular the Japanese word Tokkyo, can not be assumed to have the same legal definition as the word patent in English which dates back to letters patent issued by the Crown in the 17th century. Tokkyo means literally "special permission" and there is a wealth of difference underlying the meaning of these concepts. Still less can it be assumed that a petty patent is coterminous in meaning with Jitsuyo Shin'an, or even that the expression "petty patent" means the same in Australia as it does in the United States. Sen' yo Jisshiken does not mean quite the same thing as "exclusive license" and much misunderstanding can arise through the loose usage of these terms. Japanese patent application forms for instance contain the phrase Tokkyo Seikyu no Han'i (lit: scope of the patent claim) whereas U.S., British and Australian forms merely speak of "claim(s)".

In each case it is the claim, (or scope of the claim) that is protected in law. Strictly speaking there is no such thing as a "breach of patent"; there is only breach of claim. For this reason $I$ have concentrated on the claims in my research. In the case of each nation they are written in a very stereotyped manner. Largely this is a matter of law and regulation but it is also a matter of usage, and it is this that makes a study of the claims responsive to a search for regularities. While the structures of Japanese and English language claims are very different there are certain equivalences that can be exploited to facilitate translation. This is particularly welcome in dealing with a structure which in both languages is required to be a "nominal sentence", or an extended noun phrase. Such structures can be extremely complex particularly when they extend for half a page or more and an understanding of the philosophy underlying the claims is essential to their successful translation.

A successful claim is expected to comprise a manner of manufacture, newness, inventiveness and utility, and claimable objects include a process, a machine, a manufacture or composition of matter. Legal systems have recently come to grips with the question of whether a lifeform can be patented and here we find ourselves at a new and problematical edge of patent law.

The question of how a claim is defined is a much vexed one and touches upon the very question of what a scientific definition is. Harold E. Potts in his "Studies in the Bearing of Other Sciences on Patent Law" Part IV 'The Logical Problem in Patent Law" argues that there is "sufficient analogy between biological sciences and invention to justify the transference to patent law of results obtained by a consideration of the doctrine of evolution". In particular there are the following methods: peripheral definition, central 
definition and teleological definition. Much philosophical debate has taken place through the centuries over the relative merits and efficacy of these forms of definition and Japanese law may be said to have accepted central definition whereby a claim is essentially characterized and typified by its central point whereas the U.S. provides a good example of the peripheral limitation system whereby a claim is defined as being operative up to a certain point and not beyond. "Means" claims, however, are also accepted in the U.S. while British law has embraced the "doctrine of equivalents" which seeks to harmonize the differing systems of definition in the courts. These differing interpretations account for the fact that much extra information is normally required in an American patent claim than in a Japanese patent claim, and even a patent for the same invention registered in the two countries is not normally a direct translation even in the area of the claim. In any case legal requirements and proforma regulations determine that applications shall be laid out in a vastly different order and the headings do not directly correspond.

\section{The Structure and Content of Patents}

Australian requirements are listed in "The Guide for Applicants for Patents" published by the Patents Trademarks and Designs Office as:

a) title

b) preamble

c) what the invention generally relates to

d) the disadvantages experienced in prior apparatus

e) like objects of the present invention

f) the general statement of the invention

g) a particular and best method of carrying out the invention

h) a statement of claim(s) defining the invention

A comparison of the structure of Japanese and U.S. patents is given below. (Table 1)

Table 1: Structure of patents

\section{Japanese order}

1. Hatsumei no Meisho (or Koan no Meisho if Jitsuyo Shin'an (name of invention)

2. Tokkyo Seikyu no Han'i (or Jitsuyo Shin' an Toroku Seikyu no Han'i) (scope of the patent claim)

3. Hatsumei no Shosai na Setsumei

(detailed explanation of the invention)

then usually

i gijutsu bun'ya (field of technology)

\section{US order}

a) Title of the Invention

b) Field of the Invention

c) Prior Art

d) Summary of the Invention object/s advantage $/ \mathrm{s}$ structure/composition

(Briefly, the Invention comprises...)

e) Brief Description of the Drawings

f) Description of the 


\author{
ii jurai gijutsu \\ (prior technology) \\ iii hatsumei no mokuteki \\ (object of the invention)
}

then sometimes

hatsumei no yoshi

(summary of the invention)

iv jisshirei no setsumei

(explanation of the embodiment)

then

$\mathrm{v}$ hatsumei no koka (effects (advantages) of the invention)

\section{Zumen no Kantan-na Setsume (brief explanation of the drawings)}

\author{
Preferred Embodiment \\ related to drawings \\ (similar reference \\ characters for similar \\ elements throughout \\ (several views, as shown \\ in the drawings)
}

Further Embodiments (as many as possible)

h) A further statement to the effect that the above is not necessarily the limit

then

\section{The Claims}

What I (we) claim is:

\author{
j) Abstract of the Disclosure \\ (50 - 250 words)
}

\section{CLAIMS}

Claims are worthy of special attention because they and not the rest of the patent documentation are the subject of legal protection. It is essential that they be precisely worded and framed and that they comply with all technical and legal requirements. The legal requirements and even the basis of scientific definition differ from one system to another and in the translation of patent claims from Japanese into English these differences must always be borne in mind. The purpose of the translation is important. If the objective is to lodge the Japanese claim in an English-speaking country and especially in the U.S., many additions of detail may be necessary in order to meet, for example, the rigorous American requirements for peripheral definition. If the objective is merely to understand what the Japanese are doing and keep Western nations abreast of the latest developments in Japanese technology then a more literal translation is in order. Here, however, it will not be absolutely necessary to retain the German-inspired structure often involving laborious expressions like "characterized in that for the purpose of...". These are usually omitted in English and words like "comprising" or "wherein" are more normally used as the transitional words linking the two main parts of the claim. It should be noted, however, that the structure of the extended "nominal sentence" is designed to define the claim per genus et differentiam. As in the classification of species in the biological sciences the claim is defined by its generic title and its "difference", the two together constituting the title of the species, or in this case the definition of the claim.

Patent claims, therefore, have a certain commonality of structure. They have:

1. a generic part normally consisting of known technology

2. a transitional expression

3. the particular definition of the new invention 
Several elements will normally be present in part 3. They may or may not have been all mentioned in part 1 . If they have all been mentioned the newness will reside in the way they are combined. It is a requirement of the patent law of all nations that a mere aggregation of elements in part 3 is insufficient to sustain a successful application. The claim must also show their method of combination and preferably also the purpose for which they are combined.

Examples of typical patent claim structures are given below (Tables 2 and 3). The English structures are collected by Tanabe Tetsu in his work Enginia no Tame no Eibun Tokkyo Nyumon (An introduction to English Language Patents for Engineers) Inter Press, Tokyo pp. 248-249. The Japanese structures have been collected by myself in the course of my present research, and are presented in the order in which they have been encountered.

Table 2: Tanabe's list of english-language patent claim construction types

Type 1

$\mathrm{X}$ comprising, in combination, $\mathrm{A}, \mathrm{B}, \mathrm{C}$ and $\mathrm{D}$

Type 2

$\mathrm{X}$ comprising $\mathrm{A}, \mathrm{B}, \mathrm{C}$ and $\mathrm{D}$

Type 3

In combination, $\mathrm{A}, \mathrm{B}, \mathrm{C}$ and $\mathrm{D}$

Type 4

For use with Y...X comprising A, B, C and D

Type 5

A including a1, a2, a3 and a4

Type 6

$\mathrm{X}$ comprising $\mathrm{A}, \mathrm{B}$, and $\mathrm{C}$, the improvement comprising $\mathrm{D}$

Type 7

in $\mathrm{X}$, in combination, $\mathrm{A}, \mathrm{B}, \mathrm{C}$ and $\mathrm{D}$

Type 8

In $\mathrm{X}, \mathrm{A}, \mathrm{B}, \mathrm{C}$ and $\mathrm{D}$

Type 9

The combination with $\mathrm{A}$ and $\mathrm{B}$, of $\mathrm{C}$ and $\mathrm{D}$

Type 10

In $\mathrm{X}$, the combination with $\mathrm{A}$ and $\mathrm{B}$, of $\mathrm{C}$ and $\mathrm{D}$

Type 11

A method of... which comprises ...-ing..., ...-ing... and...-ing ...

Type 12

A method of ... which comprises the steps of ...-ing..., ing ... and $\sim$ ing...

Type 13

In a process of ..., the improvement comprising $\sim$ ing ... and $\sim$ ing... 
Type 14

$\mathrm{X}$..., said $\mathrm{X}$ comprising $\mathrm{A}, \mathrm{B}, \mathrm{C}$ and $\mathrm{D}$

Type 15

A process for... of the formula: ...

wherein R...

Type 16

A. product... of the general formula: ...

wherein R...

Type 17

$\mathrm{X}$... having a factor which is determined by the formula: ... wherein M...

Type 18

In $\mathrm{X}$ comprising $\mathrm{A}, \mathrm{B}, \mathrm{C}$ and $\mathrm{D}$, said $\mathrm{D}$ including $\mathrm{d} 1$ and $\mathrm{d} 2$

Type 19

$\mathrm{X}$ comprising $\mathrm{A}, \mathrm{B}$ and $\mathrm{C}$, characterized by $\mathrm{D}$

Type 20

$\mathrm{X}$ comprising $\mathrm{A}, \mathrm{B}, \mathrm{C}$ and $\mathrm{D}$ whereby...

Table 3: Japanese patent claim construction types (R.M.)

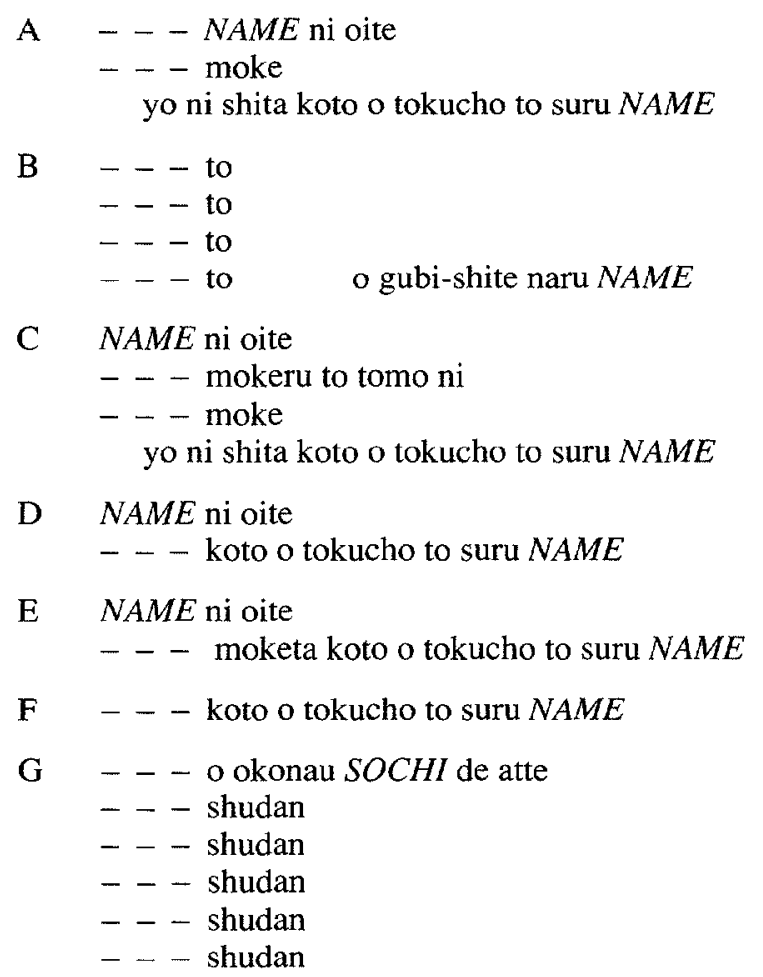


- - - shudan, narabi ni

- - - shudan

kara kosei-sareta zenki SOCHI

$\mathrm{H}$ (dependent claim)

- _ - shudan o sonai

_ _ - tokkyo seikyu no han'i dai-ikko kisai no $S O C H I$

I $\quad-\quad-$ to

- - to

- - - to o sonae

yo ni dosa suru koto o tokucho to suru NAME

J $\quad$ - - - kotei to

kotei o yu-suru koto o tokucho to suru NAME

$\mathrm{K} \quad-\quad-$ to

- - to

- - - to o gubi-shi

- - - suru koto o tokucho to suru NAME

L $\quad-\quad$ - to

- - to

- - - to

- - to

- - - to kara naru NAME ni oite

- - - o settei-shita koto o tokucho to suru NAME

M (dependent claim)

- - - to shita koto o tokucho to suru tokkyo seikyu no han'i dai-ikko kisai no NAME

$\mathrm{N} \quad-\quad-$ NAME ni oite

- - - kino o motaseta koto o tokucho to suru

O - - - o okonau yo ni shita NAME de atte

- - - ga - - - okonawareru yo ni shita NAME

$\mathrm{P} \quad-\quad-$ to

- - to

- - to o gubi-shi

- - o yu-shi

- - - shudan to

- - - shudan to o gubi-suru koto o tokucho to suru NAME

Q - - o moke

- - - o okonau yo ni shita koto o tokucho to suru NAME

$\mathrm{R} \quad-\quad-$ to

- - - to o yu-shi

- - - dosa-suru to tomo ni

- - - dosa-suru yo ni shita NAME

S $\quad$ - - NAME ni oite

- - - yo ni shita koto o tokucho to sure NAME 
- - - ga - _ - settei-sarete iru tokkyo seikyu no han'i dai-ikko kisai no NAME

$\mathrm{U} \quad$ - - - no shudan to suru NAME ni oite

- - ni sonaeta NAME

$\mathrm{V}$

(dependent claim)

- . - no shudan to suru NAME ni oite

- - - ga fuka-sare

- - - o moketa tokkyo seikyu no han'i dai-ikko kisai no NAME

W - - hoho ni shite

- - - suru koto yori naru joki no NAME

X $\quad$ - - o - . - moke

- - - o - - ni mokeru to tomo ni

- - o - . ni moke

- - o moke

- - dosa-suru yo ni kosei-shita koto o tokucho to suru NAME

Y (dependent claim)

- _ - wa - - - kosei-shita koto o tokucho to suru tokkyo seikyu no han'i dai ikko no NAME

$\mathrm{Z} \quad-\cdots$ ni oite

- - yo ni shita NAME

\section{Comment on the grammatical structure of a type a claim}

- - NAME ni oite

- - moke

- - - yo ni shita koto o tokucho to suru NAME

In this class the first $N A M E$ is the generic name, and everything before it constitutes already known technology. Ni oite is the transitional phrase. What follows is the specific description of the new claim.

- - moke indicates a new element in its composition

- - - yo ni shita indicates how it is assembled

- - - koto o tokucho to suru is a German-inspired formulaic expression not usually employed in English to indicate the characterizing function of what precedes (often following ni oite).

The final NAME is the head noun of the characterizing specific "difference". This is frequently, but not always, identical to the $N A M E$ used generically above.

\section{A Problem of Analysis of Type A}

The translator is confronted with an often very lengthy noun phrase, or nominal sentence, and the first question to be addressed is: What are the immediate constituents?

There is a temptation to regard everything prior to the final head noun as an adjunct, and thus place the split immediately before the last word. Semantics, however, and the philosophy of definition discussed above suggest that for practical purposes one should do otherwise, and on careful examination I am prepared to suggest the real split takes place immediately after ni oite.

This of course raises the question: How can a construction ending in the te form (the gerund according to Bloch) modify a construction headed by a noun? 
Two answers may be given. They are mutually exclusive but may be regarded as alternative explanations of the same phenomenon.

i) The whole passage is a nominal sentence. In such a construction the normal functional restriction on the employment of nouns breaks down i.e. the final noun takes on a verbal force. This is common in, say, Classical Chinese, and it can be seen in the celebrated English sentence "Me Tarzan". The name is the predicate. The fact that the sentence is ungrammatical according to established rules does not prevent it from having a functional grammar which is, in fact, very explicit i.e. it is signally successful in conveying meaning.

ii) Alternatively, it can be claimed that a governing verb is omitted, yet understood. This claim of course can also be made for the above English expression. This interpretation is strongly supported by the frequently used American introduction to the claims section "What I (we) claim is ...." and the Australian proforma lead: "The claims outlining the invention are as follows:..."

The Japanese proforma merely lists the heading Tokkyo Seikyu no Han'i (Scope of the Patent Claim). Yet it can be asserted that $o$ - verb at the end is understood. It could, for instance, be -o seikyu suru. This would allow the construction ending in ni oite to be the first immediate constituent. Whether moke is to be coordinated with (tokucho to) suru, with (yo ni) shita or even the verb before yo is less important. From the point of view of the translator it does not matter. Guided by semantics, my preferred interpretation coordinates it with shita.

\section{THE TRANSLATION OF CLAIMS: TWO CASE STUDIES INVOLVING TYPE A AND TYPE D}

What follows is a study of the translation methodology of a claim of Type A, followed by the application of the same methodology to a claim of Type D.

1. First, the Japanese claim (see Appendix 1) is presented and is followed by the Australian claim (Appendix 2) for the same invention. It will be noted that the Englishlanguage claim is longer than the Japanese claim and for reasons described above contains further information. Since the extra information is in this case appended at the end, it is easily identified. For the purposes of the rest of this examination it is ignored.

2. Next the order of immediately identifiable, independently translatable units within the Japanese claim is compared with the order of similarly identifiable units in the English claim (see Appendix 3). Originally the total word order was compared but this method was found to be unnecessarily cumbersome and the results are omitted here. Since the basis of the selection of the units presented is their immediate independent translatability they are capable very largely of pre-treatment and hence need be of no special concern in a study of the comparative syntax of the two claims. This is not to say that they require no internal treatment; it is merely to say they have their own regularities (e.g. an English prepositional phrase equals a Japanese postpositional phrase). Where special treatment is required it will be outlined in the rules to be evolved in the translation procedures based on the blocks outlined in Appendix 5 a-d. This reduction from words to identifiable translatable units has been found greatly to facilitate the overall analysis while greatly clarifying the exposition. Even more importantly it greatly facilitates the eventual translation.

3. The Japanese claim is analysed into its major constituent parts in Appendix 4. This partial analysis is, of course, the basis of its classification as a Type A claim.

4. In view of the length of the total claim it is thereupon further analysed in four separate blocks (Appendix $5 \mathrm{a}$-d). The 1st Immediate Constituent is treated as one block 
(Appendix 5a), and the 2nd Immediate Constituent is divided into three (Appendix $5 \mathrm{~b}$-d). The basis of the division into Immediate Constituents is discussed above under "A Problem of Analysis of Type A". The subanalysis within each block is set out diagrammatically with adjunct-words, adjunct nouns, head nouns, particles and verbs (including quasi-verbs) listed separately in the vertical columns and with adjunct-words and adjunct nouns listed horizontally before their head nouns along with all attendant postpositional particles. The original word order of the Japanese claim is maintained by reading left to right, and then by taking the lines in turn from the top down.

5. With the aid of this syntactic analysis a body of translation rules (Appendix 6) is proposed for the successive translation of the Japanese units as they appear in Appendix 5 a-d into an acceptable English word order. The translation rules are based on reading right to left, and then from the bottom up within each immediate constituent, taking the Ist Immediate Constituent first.

6. A finalized English version (Appendix 7) is now presented, in the form produced by the process described in 5. This is, of course, very similar to the complete English passage mentioned in 1. It is submitted that the differences are slight and merely idiomatic, and do not affect the meaning or the acceptability of the English passage. It is claimed, in short, that the differences are the result of optional variations of English expression or syntax which do not merit the inclusion of special rules in the translation methodology.

7. A Japanese claim of Type D (Appendix 8) is now presented. Here a pre-existing English version is not offered, and translation is attempted by following the rules mentioned in 5 for Type A. Since Type D is similar to Type A and is in fact simpler, it has been anticipated as likely that Type A translation rules will apply. This time only lexical items such as may be found in a dictionary are supplied for the exercise. Minimal extra rules (see Appendix 9) are applied, and, importantly, it will be noted that they in no way contradict the rules outlined in 6 for Type A. They are entirely compatible extensions for coping with new situations as they arise through the encounter with new linguistic phenomena.

8. The final result (Appendix 10) shows an acceptable English translation of the Type D example. This means that the methodology evolved above has worked successfully in this case. While it is early days to claim that the methodology is therefore validated, the results are clearly encouraging and it appears that while the system is not complete it is at least capable of forming a basis for further refinement upon the progressive encounter with new linguistic phenomena. Furthermore, since the steps can be enumerated and placed in order, it is submitted that the process recommends itself to eventual mechanical translation.

Appendix 1: A Japanese claim of type A

\section{Hatsumei no Meisho Sukyan'auto Hoshiki}

\section{Tokkyo Seikyu no Han'i}

Memori to, gai memori no kakikomi-adoresu o shitei-suru kaunta to, gai kaunta no kaunto-atai yori nin'i no atai o genjite yomidashi-adoresu o shitei-suru ensanki to kara kosei-sareru shifuto-rejisuta ni tai-suru sukyanauto hoshiki ni oite, joki memori no yomidashi-adoresu o keisan-suru tame no ensanki no nyuryoku-gawa ni sentaku-kairo o moke, joki sentaku-kairo ni nyuryoku-sareru shifuto-dansu o kimeru teisu to sukyan- 
adoresu no izure ka ippo o, joki sentaku-kairo ni nyuryoku-sareru sukyan-kyoka-shingo ni ojite sentaku-shi, joki sentaku-kairo ni yotte sentaku-shutsuryoku-sareru deta o joki ensanki no nyuryoku- tanshi ni nyuryoku-suru yo ni shita koto o tokucho to suru sukyan'auto hoshiki.

Appendix 2: Australian equivalent

Name of Invention

Scan-out System

\section{Claim}

1. A scan-out system for a shift register, the shift register being formed by a memory, a counter for designating a write address of the memory and an operator for subtracting an arbitary value from the count value of the counter to designate a read address of the memory, said scan out system comprising a multiplexer provided at the input side of the operator for calculating the read address of the memory, wherein either a constant which determines the number of shift stages of the shift register or a scan address, which are both input to the multiplexer, is selected in accordance with a scan enable signal input to the multiplexer and data selectively output from the multiplexer is input as said arbitary value to the input terminal of the operator*, and each stage of the shift register is assigned a corresponding scan address so that during scanning as determined by the scan enable signal input to the multiplexer the scan address corresponding to the stage to be scanned is input to the operator together with the count value to effect subtraction of the scan address from the count value of the counter so that irrespective of the count value the operator will output a value defining the read address of whichever register is then equivalent to the stage to be scanned.

*end of the information provided in the Japanese claim.

Appendix 3: Comparative order of independently translatable units

\section{Japanese}

\section{Sukyan'auto-hoshiki}

1. Memori to

2. gai memori no

3. kakikomi-adoresu o

4. shitei-suru

5. kaunta to

6. gai kaunta no

7. kaunto-atai yori

8. nin'i no atai o

9. genjite

10. yomidashi-adoresu o

11. shitei-suru

12. ensanki to

13. kara

14. kosei-sareru

15. shifuto-rejisuta ni
Equiv. Eng. No. English

\section{Scan-out system}

6

10

9

8

7

16

15

14

13

18

17

11,12

5

4

2,3

3. the shift-register

4. being formed

5 . by

6. a memory

7. a counter

8. for designating

9. a write address

10. of the memory

11. and

12. an operator

13. for substracting

14. an arbitrary value

1. A Scan-out system

2. for a shift-register

Equiv. Jap. No

15. from the count value

17

16,15

15

14

13

1

5

4

3

2

$12 \mathrm{ii}$

$12 \mathrm{i}$

9

7 
16. tai-suru

17. sukyan'auto-hoshiki ni

18. oite

19. joki memori no

20. yomidashi adoresu o

21. keisan-suru

22. tame no

23. ensanki no

24. nyuryoku-gawa no

25. sentaku-kairo o

26. moke

27. joki sentaku kairo ni

28. nyuryoku-sareru

29. shifuto-dansu o

30. kimeru

31. teisu to

32. sukyan-adoresu no

33. izureka ippo o

34. joki sentaku-kairo ni

35. nyuryoku-sareru

36. sukyan-kyoka-shingo ni

37. ojite

38. sentaku-shi

39. joki sentaku-kairo ni

40. yotte

41. sentaku-

4.2. shutsuryoku-sareru

4.3. deta 0

44. joki ensanki no

4.5. nyuryoku-tanshi ni

4.6. nyuryoku-suru

4.7. yo ni

48. shita

49. koto o

50. tokucho to

51. suru

52. sukyan'auto-hoshiki
$2 i$

1

29

28

27 ii

$27 \mathbf{i}$

26

25

23

24

44

40

$41,42,43$

35,36

34

32

39

31,38

44

48

47

46

45

$54 \mathrm{ii}$

$54 \mathrm{i}$

52

53

51

57

56

55

\}

\}

22

1

1
16. of the counter

17. to designate

18. a read address

19. of the memory

20. said

21. scan-out system

22. comprising

23. a multiplexer

24. provided

25. at the input side

26. of the operator

27. for calculating

28. the read address

29. of the memory

30. wherein

31. either

32. a constant

33. which

34. determines

35. the number

36. of shift stages

37. of the shift register

38. or

39. a scan-address

40. which

41. are

42. both

43. input

44. to the multiplexer

45. is selected

46. in accordance

47. with a scan-enable signal

48. input

49. to the multiplexer

50 . and

51. data

52. selectively

53. output

54. from the multiplexer

55. is input

56. to the input terminal

57. of the operator
6

11

10

*

$*$

51,50

$49,48,47$

25

26

24

23

22,21

20

19

33

$31 \mathrm{i}$

30

29

29

31 ii

32

28 ii

$*$

$28 \mathrm{i}$

27

38

37

36

35

34

*

43

41

42

40,39

46

45

44 


\section{Appendix 4: Major constituents}

Main question: to what is oite subordinated?

Secondary question: to which verb is moke linked?

\section{a) Immediate Constituents}

\section{Hypothesis}

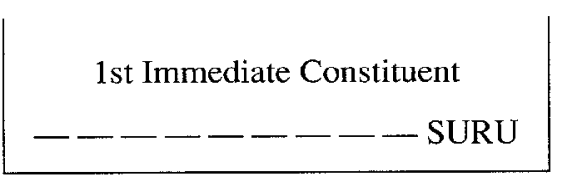

ADJUNCT

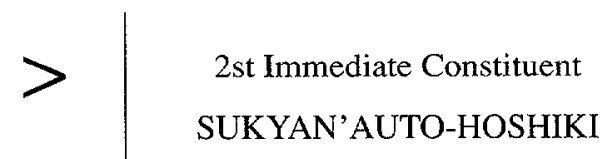

HEAD

Preferred Interpretation

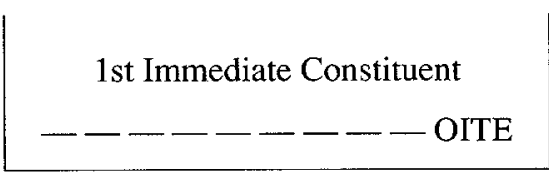

ADJUNCT

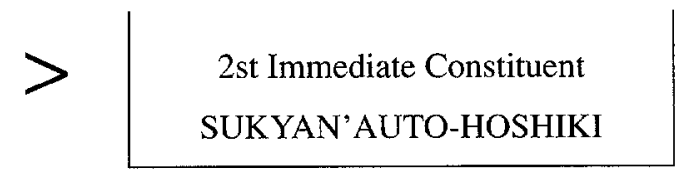

HEAD

b) 2nd Immediate Constituent

Preferred Interpretation

The ren' yokei "moke" is linked in semantic coordination with the rentaikei "shita"

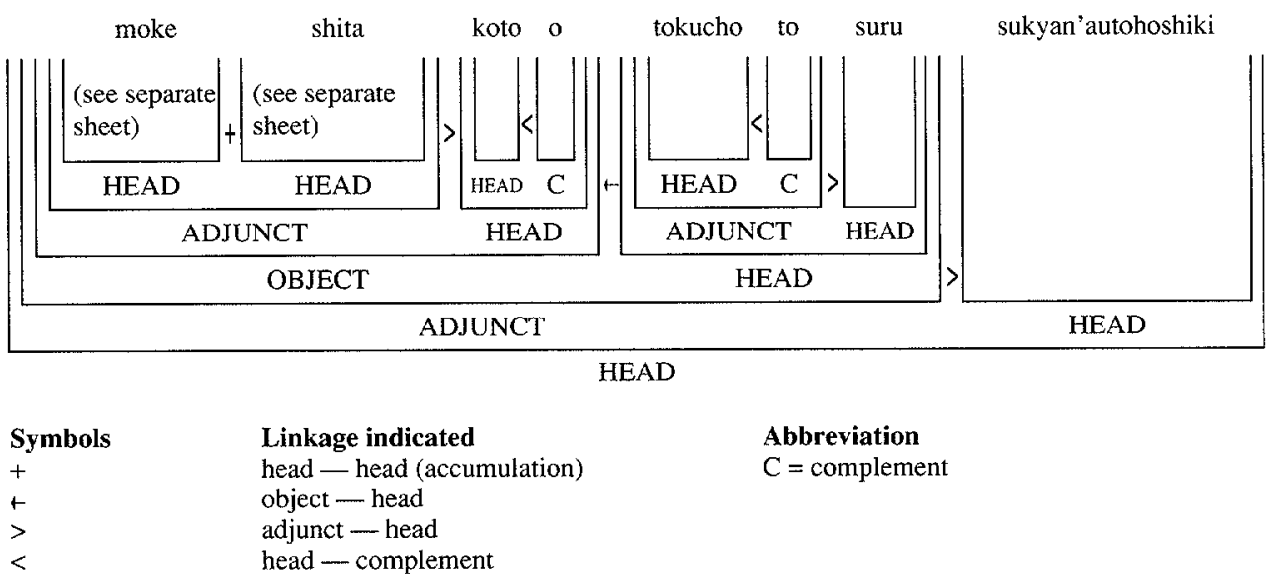




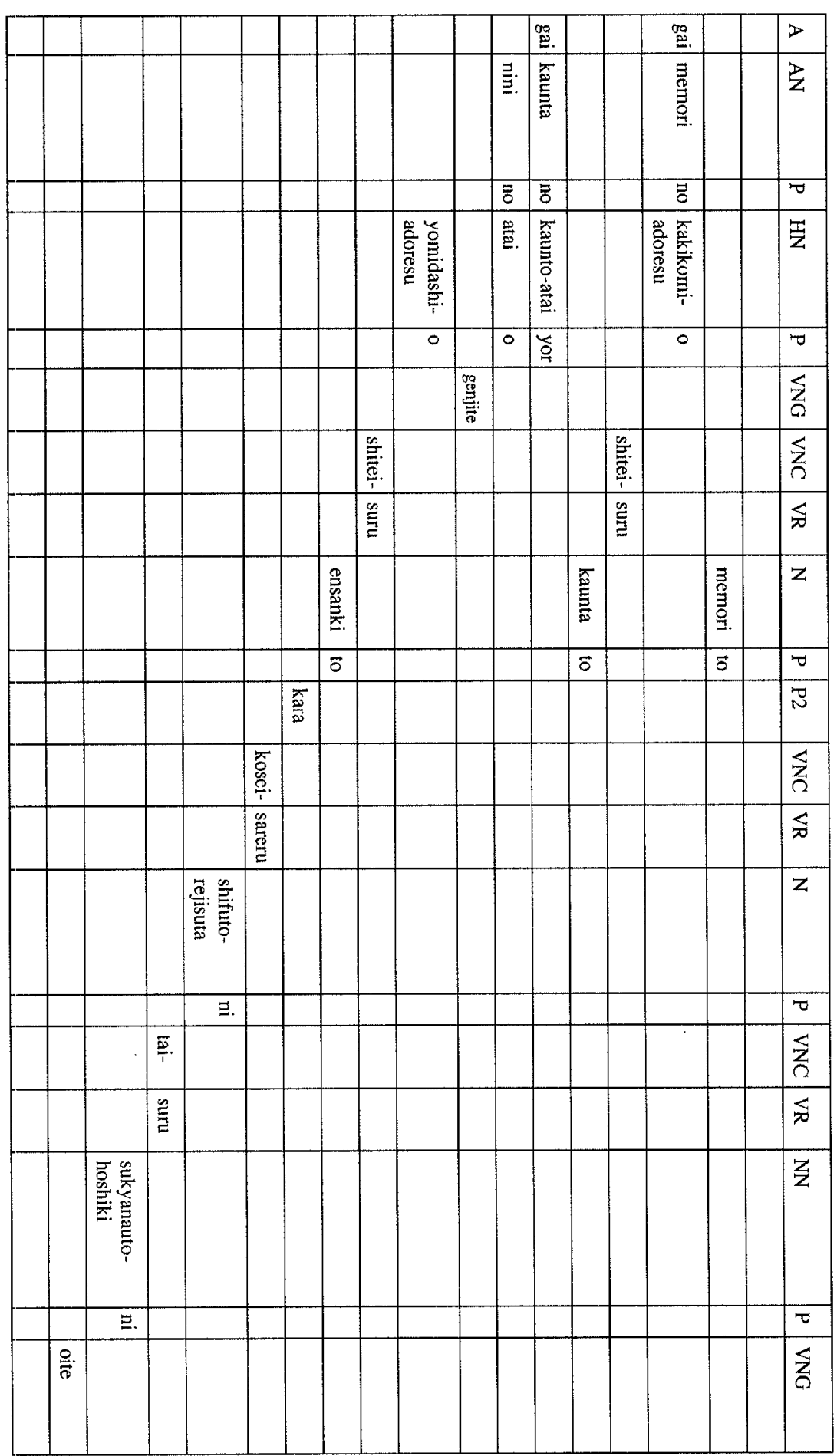

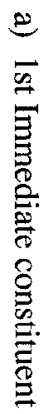

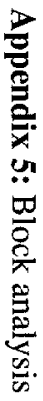




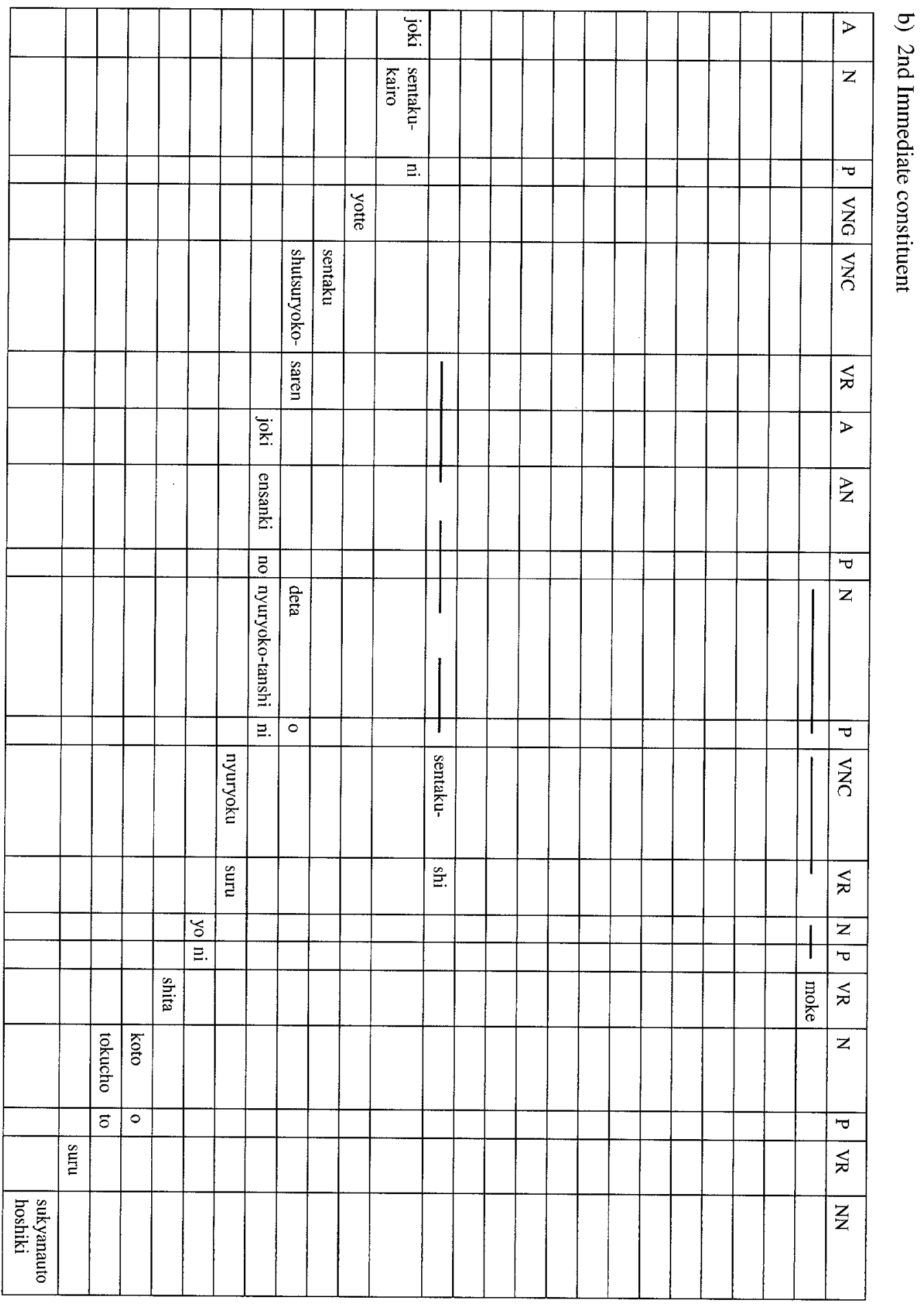




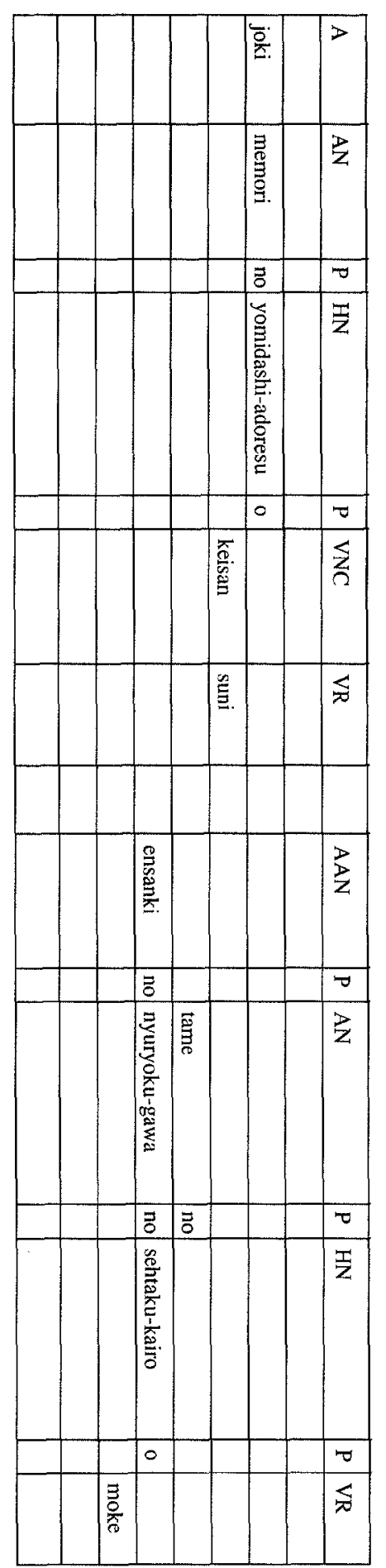

0
1
1
$\frac{2}{2}$ 

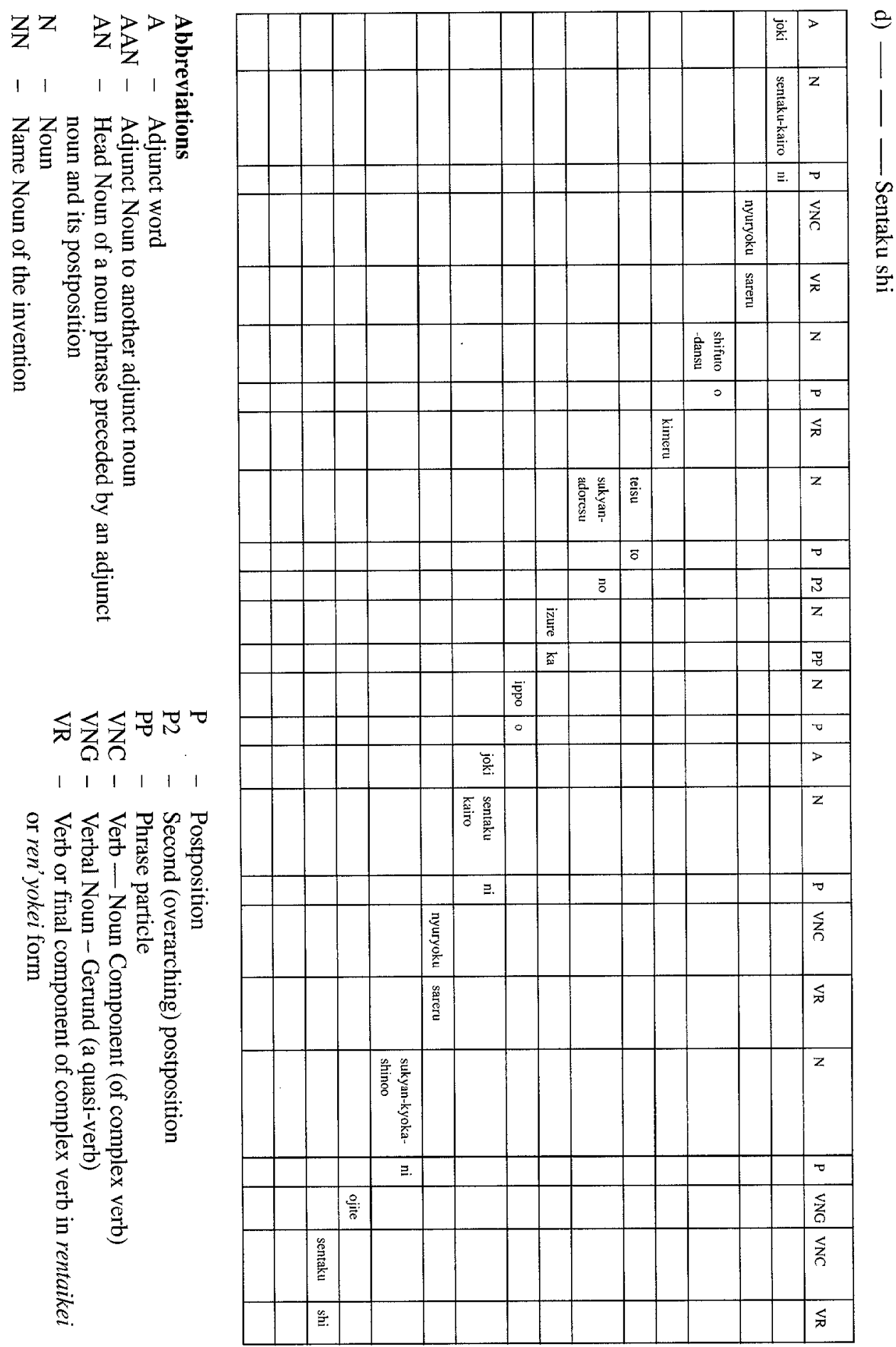
Appendix 6: Translation rules

\section{Rules for 1st Immediate Constituent}

1. Ignore ' $n$ i oite'

2. Read right to left first; then next line higher.

3. When elements ending in ' $t o$ ' appear in the same column, read highest first. Translate only the last ' $t o$ '

4. Place an indefinite article before a noun when it is first mentioned; thereafter a definite article.

5. Translate 'rentaikei' verbs (verbs followed by a noun) by ...ing form, if active voice.

6. Translate 'rentaikei' verbs (verbs followed by a noun) by '-ed' form if passive voice.

7. Translate '-te' form of verbs also by rules 5 and 6 , making provision for a preceding preposition.

8. Translate 'gai' and 'joki' before the noun to its right, but after its definite article.

9. Translate an adjunct noun of descriptive (adjectival) semantic value before the noun to its right, but after its article.

\section{Result}

A scan-out system

applying to

a shift register

formed

from

a memory

a counter

designating

a read-address

of

the said memory and

an operator

designating

the read address

(by) subtracting

an arbitrary value

from

a count value

of

the said counter

\section{Comment}

may be substitued by 'for'

may be repeated with a preceding definite article followed by a comma and 'beingintroducing a nominative abstract construction

may be substituted by comprising

'for' may be inserted before participle (making it a gerund)

for may be inserted before participle making it a gerund

the definite article may replace the indefinite in a noun relating to an expected function of a noun already translated 
Rules for 2nd Immediate

\section{Constituent}

a) - - moke

10. Render 'moke' by

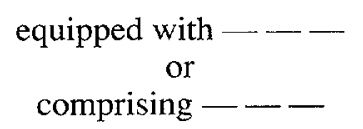

Result

Comment

comprising

a multiplexer

on

the input side

use the definite article for

of directional nouns and phrases

the counter

for (the purpose of)

calculating

translate 'tame no' as 'for'in 'for

the purpose of'

the read address

of

the said memory

\section{b) - - sentaku-shi}

11. Render FINAL NOUN and preceding '...yo ni shita koto o tokucho to suru' by "wherein"....

12. When the ren'yokei of a verb and another verb appear in the same column, rend the highest (ren' yokei) verb first, and add 'and' after its predicate, unless it is in a list of three or more, in which case only the last of the ren'yokei verbs should take 'and' after its predicate.

13. Where no subject indicator exists, transform the verb into the passive voice, and select the nearest available (i.e. not governed by another verb form) noun followed by ' $O$ ' (i.e. its object) as the subject.

14. Translate this noun (the selected noun in Rule 13) and any adjunct to it before 1) the verb and 2) any other noun in the same column followed by any particle other than ' $o$ '- in that order.

15. As a rider to Rule 3 , when two nouns are noun phrases linked coordinately e.g. by ' $t o$ ' are preceded by an adjunct, in order to avoid mistranslation of the classical case of ambiguity adj + noun + noun, translate the latter noun or noun phrase first and the adjunct last. 


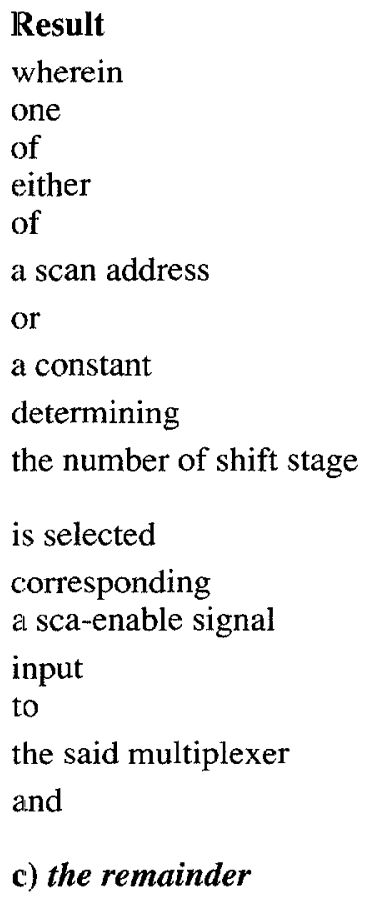

\section{Result}

dlata

selected and output

by

the said multiplexer are input terminal of

the said operator

\section{Comment}

translate :- to - no izure

ka no ippo - as 'one of either of - or - '

use the definite article before what is determined

may be translated 'in accordance with'

\section{Comment}

translate ni yotte 'by means of' or 'by'

Appendix 7: Result (in continuous form) of application of the above rules

A scan-out system applying to a shift register formed from a memory, a counter designating a read-address of the said memory and an operator designating the readaddress by subtracting an arbitrary value from a count value of the said counter, comprising a multiplexer on the input side of the counter for (the purpose of) calculating the read-address of the said memory, wherein one of either of a scan-address or a constant determining the number of shift stages is selected in accordance with a scan-enable signal input to the said multiplexer, and data selected and output by the said multiplexer are input to the input terminal of the said operator. 
Appendix 8: A japanese claim of type D

1. Hatsumei no Meisho

Yosetsu-kan no Burankugaido-yo Z-ba

\section{Tokkyo Seikyu no Han'i}

Yosetsu-kan no ento-jo buranku o yosetsu-kotei o gaido-suru Z-ba ni oite, tsujo no Zjo gaido-bu no kawari ni aitaiko-suru L-gata-men o kosei suru 2-ko 1-kumi no burokku o gubi-seshimeta koto o tokucho to suru yosetsu-kan no buranku-gaido-yo Z-ba.

\section{Appendix 9: New rules}

1. When the generic name and the specific name differ, translate A generic name... Wherein (or characterised in that) the specific name...

2. Translate '2-ko I-kumi no': 'a pair of (following noun)'.

\section{Result}

A Z-bar

for

guiding

to

a welding process

a

cylindrical blank

of

a welding can,

wherein

the Z-bar

for use as

the blank guide

of the welding can

has

a pair of

blocks

forming

L-shaped surfaces

facing each other

in

place

of

the usual

Z-shaped guide

\section{Comment}

gubi-seshimeta: has, is equipped with, is fitted with, comprises

kara kosei-suru: formed from o kosei-suru: forming

or 'stead' 
Appendix 10: Result in continuous form

\section{Name of the Invention}

A Z-Bar for Use as a Blank-guide of a Welding Can

2. Scope of the Claim

A $\mathrm{Z}-$ Bar for guiding to a welding process a cylindrical blank of a welding can, wherein the Z-bar for use as the blank-guide of the welding can has a pair of blocks forming L-shaped surfaces facing each other in place of the usual Z-shaped guide.

\section{BIBLIOGRAPHY}

TANABE, T. (1981): Enginia no Tame no Eibun Tokkyo Nyumon (An Introduction to English Language Patents for Engineers), Tokyo, Inter Press.

POTTS, H.E. (1981): "Studies in the Bearing of Other Sciences on Patent Law: Part IV The Logical Problem of Definition in Patent Law," Tanabe T. Enginia no Tame no Eibun Tokkyo Nyumon, pp. 309-322, Tokyo Inter Press.

MILLER, R.A. (1970): Bernard Block on Japanese, New Haven, Conn. Yale U.P.

JAPANESE PATENTS (a) 58-121458; (A) 60-180678

AUSTRALIAN PATENT AU-B-91088/82 